\section{New Look for Gas}

IT would have been difficult to predict ten years ago the speed with which the energy pattern of the United Kingdom has been transformed by the discovery of natural gas. As Sir Henry Jones, chairman of the Gas Council, explained in his Thomson Lecture to the Society of Instrument Technology on October 9, the picture changed on August 14, 1959, when the Slochteren field, containing at least $60 \times 10^{12}$ cubic feet of gas, was discovered off the Dutch coast. It was not until 1964 that gas was found in the North Sea, and now Sir Henry puts the potential supplies at 3,000 million cubic feet a day for the next 20 to 30 years-as usual, he is more optimistic than the Ministry of Power, which believes that the fields can bring in 2,000 million c.f.p.d.

So far, all Sir Henry's optimism has been justified, but he is determined to preserve a sense of proportion. Over a full year, the ministry prediction is equivalent to 25 million tons of coal; perhaps, if this rate could be doubled within ten years, the coal equivalent would be 50 million tons a year. "Natural gas will provide a most valuable addition to our country's resources, but it will not replace all the coal used nor will it render imports of oil unnecessary." Sir Henry emphasized the Gas Council view that supplies must be built up quickly"a high speed build-up seems to me to be absolutely essential." But negotiations on terms and conditions of gas supply had not been easy, he admitted, and expressed the hope that purchase terms could be settled fairly quickly.

Unlike his opposite number at the National Coal Board, Lord Robens, Sir Henry believes in nuclear power stations. Fission, or possible fusion reactions, will, he believes, soon be able to supply the cheapest heat available for very large installations working at high load factor, and the capital cost of nuclear stations will fall. But, as a reassurance to those in the gas, coal and petroleum industries, Sir Henry quoted the laws of thermodynamics. Fuel used in heat engines to generate electricity will, he thinks, always exceed the heat equivalent of the electricity produced, and the cost of electricity transmission, on a heat equivalent basis, will be greater than that for coal, oil or gas. For the provision of heat, he said, fuel burned at the point of use is likely to remain more economic for very many purposes. With that the coal, oil and gas industries will have to be satisfied.

\section{Expanding Services}

The Post Office is undergoing a considerable reorganization in an endeavour to become a more forward-looking and efficient public service industry. The Government decided in August 1966 to convert the GPO from a civil service department to a public corporation, and the newly published report and accounts for 1966-67 (HMSO, 14s.) gives details of the form it will take, provided the requisite legislation is passed by Parliament. The new corporation, known as the Post Office, will take over in 1969 , with responsibility for all activities of the present GPO except the savings department. Total assets, numbers of staff employed and plans for capital investment will put the Post Office among the ten largest industrial concerns in the world.

Activities will be divided into the two categories of Post and Telecommunications and, unless savings can be made by particular co-ordination in some places, they will be run as separate services. Enquiries have been made into ways of raising profitability and productivity, by McKinseys Inc., in the Post section, and by the Organization and Efficiency Branch of the Inland Telecommunications Department in their own field. Recommendations are already being put into effect, and the saving of $\$ 500,000$ a year in telecommunications is only a beginning.

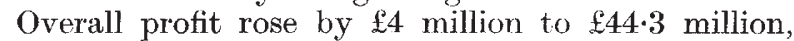
of which $\mathfrak{f} 6 \cdot 6$ million came from the post services. Higher charges accounted for most of the increased income of $£ 21.8$ million in the postal section, bringing the total income here to $£ 340 \cdot 6$ million. 'Three-quarters of the increased expenditure went on pay awards, but manpower productivity rose by more than 1 per cent. Mechanization is being introduced wherever possible, in the handling of post, for example, so that letters and parcels are arriving faster than before. Ninetythree per cent of letters now arrive within a day of posting. Experiments are being made into parcel delivery services with cheaper local tariffs, and minibus post services. A new look is also creeping into postmen's uniforms. Large scale investigations were made into the possibilities of a two-tier letter system for maximizing labour efficiency, when charges would be related to speed of delivery. Work on the National Giro continues, and market research has given promising results.

In the telecommunications section income rose to $£ 441 \cdot 8$ million, but profit fell by $£ 1 \cdot 6$ million to $£ 37 \cdot 7$ million. 747,000 new telephone connexions were made, but there is still a waiting list of 115,000 , because of shortages of equipment. The numbers of local, trunk and overseas calls rose during the year, and these were dealt with more efficiently, either by operators or by automatic exchanges. Improvement of service for subscribers has been given priority, with good effect. $£ 211 \cdot 6$ million of the capital expenditure of $£ 242$ million was for expansion of the telccommunications system. Manpower productivity rose by more than 8 per cent, partly because it was realized that it takes one man, not two, to install a new phone. Both Telex and Datel services have continued to expand, but during the year the overall growth rate of the telecommunications section has slowed down. This is thought to be a temporary situation, due to the squeeze, and as rapid expansion of investment is expected to be required in the near future, minimization of costs is an important aim.

The Post Office seems to be preparing to launch into profitable corporation business with a splash, but despite this healthy state, increased post office charges are likely to be introduced. The Postmaster General, the Rt. Hon. Edward Short, has explained why these increases are thought to be necessary. The sheer size of the telecommunications expansion programme will be beyond the resources of the Post Office. More money will have to be borrowed from the Exchequer, for which interest will have to be paid. The interest

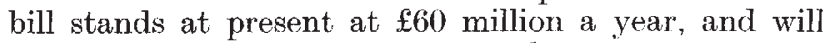
rise further with the increases in borrowing. 'To ask why the telecommunications system should be selfsupporting is to come back to the question of how the resources of the country are best allocated. For this reason the proposed price increases are being put before the Prices and Incomes Board. 